\title{
MODEL LATIHAN SMASH DALAM PERMAINAN BOLA VOLI UNTUK PEMULA
}

\author{
Samsu Nurfalah ${ }^{1}$, Achmad Sofyan Hanif ${ }^{2}$, Yasep Satyakarnawijaya ${ }^{3}$ \\ ${ }^{1,2,3}$ Pendidikan Jasmani Pascasarjana Universitas Negeri Jakarta \\ Jalan Rawamangun Muka, Rawamangun, Pulo Gadung, \\ Kota Jakarta Timur, Indonesia \\ 1e-mail: mochsamsu92@gmail.com
}

\begin{abstract}
Abstrak
Penelitian dan pengembangan ini untuk menghasilkan produk berupa model latihan smash dalam permainan bola voli untuk pemula dan memperoleh data tentang pengembangan dan penerapan model latihan smash serta untuk mengetahui efektifitas model yang dihasilkan. Penelitian ini menggunakan metode Research and Development dari Borg and Gall. Subjek penelitian ini adalah anggota ekstrakulikuler Siswa SMA berjumlah 30 orang. Tahapan penelitian ini yaitu analisis kebutuhan, evaluasi ahli, ujicoba kelompok kecil, ujicoba kelompok besar, dan uji efektifitas model menggunakan tes smash bola voli digunakan untuk mengetahui tingkat kemampuan smash atlet pemula, pretest diperoleh nilai ratarata sebesar 15,05, dan posttest diperoleh nilai rata-rata 20,75. Berdasarkan analisis data menggunakan uji t disimpulkan bahwa terdapat perbedaan yang signifikan antara hasil pre-test dan posttest diberikan perlakuan model latihan smash yang dikembangkan. Dengan ini model latihan smash dalam permainan bola voli untuk pemula efektif untuk meningkatkan kemampuan smash bola voli.
\end{abstract}

Kata Kunci: model, latihan, smash, bola voli

\begin{abstract}
This research and development resulted in a smash training model in volleyball games for beginners and obtained data on the development and application of the smash training model and to determine the effectiveness of the resulting model. This study uses the Research and Development method of Borg and Gall. The subjects of this study were extracurricular members of high school students studying 30 people. The stages of this research are needs analysis, expert testing, small group testing, large group testing, and model effectiveness testing using volleyball smash tests are used to determine the level of smash ability of beginner athletes, pretests get an average value of 15,05, and posttest get an average value of 20,75. Based on data analysis using the t test it was concluded that there were differences between the pre-test and posttest results given the training model of the developed smash training. With this model the smash practice in volleyball games for beginners is effective for improving the volleyball smash ability.
\end{abstract}

Keywords: model, exercises, smash, volleyball

\section{PENDAHULUAN}

Sekolah sebagai lembaga pendidikan formal dalam masyarakat mempunyai peranan yang sangat penting dalam mengantarkan masyarakat pada kehidupan yang lebih baik. Pendidikan formal merupakan suatu aktifitas yang 
sudah diatur secara sistematis yang sangat jelas dan terencana dengan tujuan tertentu, keberhasilan bidang pendidikan akan berbanding lurus dengan proses belajar yang dijalankan. Tolak ukur sederhana dalam dunia pendidikan terjadinya interaksi timbal balik antara guru sebagai pengajar dan anak didik sebagai subjek dalam proses pembelajaran.

Cabang olahraga bola voli merupakan permainan bola besar yang menggunakan net, bola dan lapangan sebagai peralatan dan fasilitas lainnya, cabang olahraga bola voli dimainkan oleh dua tim yang saling berlawanan masing-masing tim terdiri enam orang. Permainan bola voli memiliki tujuan untuk mendapatkan point sebanyak-banyak untuk memenangkan setiap setnya, dalam pertandingan dituntut mempertahankan dan menggagalkan serangan tim lawan untuk mendapatkan point. Untuk memenangkan pertandingan setiap tim harus memenangkan tiga sett dari lima sett dalam satu games. Dalam permainan bola voli memerlukan kerja sama yang sangat baik antar anggota tim nya, selain kekompakan dan respon yang cepat permainan bola voli juga membutuhkan kondisi fisik yang prima, mental bertanding, dan teknik permainan yang tinggi agar mampu bertahan dan melakukan serangan dengan efektif dan efisien. Secara sederhana permainan bola voli memiliki tiga teknik dasar untuk mempertahankan atau memenangkan game yaitu servis, smash, dan blok.

Permainan bola voli mengalami perkembangan yang sangat jauh dari bentuk yang sederhana sampai bentuk yang modern baik secara tujuan atau secara peraturan permainan. Sekarang ini permainan bola voli bukan saja dimainkan untuk tujuan kesehatan dan kebugaran tubuh, tetapi sudah berkembang menjadi sebuah industri olahraga yang menuntut adanya prestasi.

Pembinaan dan pengembangan olahraga prestasi dilaksanakan untuk tujuan pencapaian prestasi setinggi-tingginya dimulai dari tingkat lokal sampai tingkat dunia, dari mulai tingkat pelajar sampai tingkat atlet profesional. Untuk mencapai prestasi yang tinggi membutuhkan proses yang sangat panjang dan hanya bisa dilakukan dengan melalui pembinaan dan latihan-latihan secara maksimal bahkan diperlukan pembinaan sejak usia dini. Dengan program yang terencana dan terstruktur dan dilakukan secara terus menerus dalam waktu yang 
sangat panjang sampai mencapai tujuan tersebut dan selanjutnya mempertahankan prestasi tertinggi.

Permainan bola voli memiliki tiga posisi yaitu pengumpan (tosser,), penyerang (spike), dan libero (defend). Ketiga posisi ini memiliki peran yang sama pentingnya antara satu sama lainnya, dimana permainan bola voli merupakan permainan yang dilakukan secara tim. Pemain posisi libero bertugas menahan dan memberikan bola pada pemain pengumpan (tosser) yang bertugas merangkai serangan dengan mengolah bola yang diterima dari libero menjadi upan yang pas untuk melakukan smash oleh (spike) penyerang. Tetapi tidak hanya jadi umpan yang cantik yang bisa mendapatkan point dengan mudah karena tim lawan akan melakukan blocking untuk membendung dan menggagalkan serangan. Tugas seorang spike harus dapat melihat posisi kosong pada area lawan dengan kecepatan waktu dalam hitungan detik. Dan itu bisa dilakukan secara maksimal oleh orang-orang yang terlatih, dimana dalam pelaksanaannya membutuhkan kecepatan, kekuatan, dan ketepatan sehingga berakhir mendapatkan point dan memenangkan games.

Berdasarkan obesrvasi di lapangan dan analisia permainan pada kompetisi bola voli tahunan antar Sekolah Menengah Atas (SMA) dengan cakupan wilayah kabupaten Bandung Barat, Kabupaten Purwakarta, Kota Bogor, Kota Sukabumi, kabupaten Sukabumi dan Kabupaten Cianjur diselenggarakan oleh Himpunan Mahasiswa Pendidikan Jasmani Kesehatan dan rekreasi pada tahun 2016, pada event Pekan Olahraga PKJR (POP) yang bertempat di lapangan kampus Universitas Suryakancana. dimenangkan oleh SMA dari Kabupaten Bandung barat. SMA perwakilan dari kabupaten Cianjur hanya mampu sampai pada babak perempat final. Kemudian peneliti melakukan wawancara dengan guru SMK Bela Nusatara, SMKN 1 Cianjur dan SMAN 1 Ciranjang yang berhasil masuk ke babak perempat final. Karena hasil obervasi dan analisa pertandingan tim sekolah tersebut, mereka memiliki permainan yang bagus dan kerjasama tim yang bagus, tetapi ketika melakukan serangan, serangan-serangan tersebut sering terbendung dan bisa diselamatkan oleh tim lawan. 
Berdasarkan latar belakang masalah diatas maka perumusan masalah dalam penelitian ini yaitu (1) bagaimanakah model Latihan smash permainan bolavoli untuk pemula?, Apakah model latihan smash efektif untuk meningkatkan smash dalam permainan bolavoli untuk pemula?.

Model merupakan abstraksi dunia nyata atau representasi peristiwa kompleks atau sistem dalam bentuk naratif, sistematis, grafis atau lambang lain. Semua orang dapat merancang model-model yang membaca membuat pemikiran tentang dunia dan sekelilingnya. Tanpa model orang akan mempunyai masalah dalam pemecahan persoalan kehidupan sehari-hari. Pengembangan model merupakan rangkaian proses intensif yang berkaitan dengan model sebelumnya, evaluasi siswa pada saat ini dan fondasi keilmuan yang kuat.

Dalam permainan bola voli memerlukan kerja sama tim yang sangat baik, akan tetapi kemampuan dan keterampilan setiap individu itu menjadi modal dasar untuk menjadikan sebuah kemampuan yang kolektif. Secara aturan dasar bahwa satu pemain dalam satu realy pemain hanya bisa satu pukulan. Secara tujuan permianan bola voli ialah mendapatkan point untuk memenangkan pertandingan dengan cara melakukan serangan yang efektif. Serangan dalam permainan bola voli sangat dinamis dan membutuhkan variasi yang terus gonta ganti, guna untuk menyulitkan tim lawan menggagalkan arah serangan yang akan di lakukan.

Tidak ada aturan yang membatasi variasi smash yang digunakan selagi itu tidak melanggar peraturan permainan bola voli yang sudah baku, artinya dalam membagun tim yang hebat dan bisa berprestasi memerlukan proses yang sangat panjang. Dimana kerja sama antar individu harus sudah terbangun sangat baik, model latihan smash yang digunakan sudah sangat variatif, maka akan meningkatkan kemampuan serangan individu dan tim sangat efektif dan mematikan.

Smash merupakan sebuah usahan yang dilakukan untuk mendapatkan point, maka dengan itu smash yang dibangun harus membuat bloker tim lawan kebingungan dan tidak mampu diprediksi oleh bloker tim lawan, baik dengan kecepatan umpan dan smasher, variasi smash yang dilakukan menggunakan pemain posisi belakang yang sangat sulit untuk di block (back attack). Melatih 
posisi dan variasi smash harus menggunakan model-model latihan yang efektif dan efsien serta memiliki inovasi yang terbarukan dan mudah untuk di pahami khususnya untuk pemula.

Proses dari latihan merupakan dasar dari peningkatan efektifitas kemampuan jasmani. Oleh karena itu, harus terlebih dahulu mengerti dan memahami arti dari latihan. Latihan menurut Bompa (2009:2) adalah proses dimana seorang atlet dipersiapkan untuk performa tertinggi. Johansyah (2013:13) menyatakan bahwa penyusunan atau perencanaan program latihan adalah mengarahkan latihan selama jangka panjang (waktu tertentu. Tujuannya adalah memaksimalkan adaptasi fisiologi, yang pada akhirnya dapat meningkatkan prestasi atau penampilan seorang atlet. Sedangkan Lumintuarso (2013:45) mengatakan bahwa latihan pada dasarnya merupakan proses pendidikan yang bertujuan untuk membantu individu dalam meningkatkan kemampuan kognitif, afektif, dan psikomotornya.

Berdasarkan penjelasan beberapa pendapat ahli diatas dapat simpulkan latihan merupakan suatu rangkaian dari beberapa proses latihan yang tersusun secara sistematis, dilakukan secara berulang-ulang, kian hari jumlah beban latihannya kian bertambah. Sistematis maksudnya bahwa pelatihan yang dilaksanakan secara beraturan, berencana, sesuai jadwal, menurut pola dan sistem tertentu, metodis, berkesinambungan dari yang level mudah ke yang lebih sulit. Berulang-ulang maksudnya bahwa gerakan yang baik tidaklah bisa dilakukan secara langsung namun dengan proses pengulangan yang terus menerus sampai terjadi gerak otomatis yang baik.

Menurut Ahmadi (2007:7) bola voli merupakan suatu permainan yang kompleks yang tidak mudah dilakukan oleh setiap orang, sebab dalam permainan bola voli dibutuhkan koordinasi gerak yang benar-benar bisa diandalkan untuk melakukan semua gerakan yang ada dalam permainan bola voli. Meskipun begitu hal tersebut tidak menghalangi masyarakat untuk mempelajari lebih mendalam karena ketertarikan yang terjadi di masyarakat tinggi. Maka dari itu, tidak heran jika permainan yang dominan menggunakan tangan ini sering dimainkan oleh 
anak-anak hingga orang dewasa. Olahraga ini sangat berguna sebagai pendidikan karakter, sarana rekreasi, maupun sebagai tujuan menggapai prestasi.

Teknik yang paling efektif dan banyak digunakan dalam melakukan serangan untuk memperoleh nilai adalah smash, Menurut Yunus dalam Riyadi (2015: 32) bahwa smash adalah pukulan yang utama penyerangan dalam mencapai kemenangan. Dewi berpendapat adalah Smash merupakan perpaduan gerakan yang tidak dapat dipisahkan. Kerjasama antar otot antara lain otot lengan, otot perut, otot tungkai, otot pinggul, otot bahu, dan kelentukkan togok sangat mempengaruhi keberhasilan dalam melakukan smash. Pranopik (2017) mengemukakan smash adalah teknik paling sulit dan memiliki gerakan yang komplek sehingga teknik smash harus dilatihkan pada atlet sejak dini karena pada usia dini merupakan tahap yang rentan dengan kesalahan gerak. Kemudian ditegaskan oleh Mukhwinder Smasher plays in front of the net, performing spike and block. Lower limb muscle power, expressed by the numerous jumps performed during the games, which are important both for the attacking and blocking action. Berdasarkan beberapa pendapat ahli di atas dapat di buat sebuah kesimpulan bahwa modal utama untuk memenangkan poin ialah kuncinya dalam melakukan smash yang mematikan.

\section{METODE}

Penelitian dan pengembangan yang dipakai dalam penelitian ini yaitu penelitian dan pengembangan Borg and Gall. Dengan tujuan lebih konstruktif, Inovatif dan variatif untuk diaplikasikan serta lebih menarik. Penelitian dilakukan dari tahapan yang sesuai yaitu tahap awal ide sampai tahap produksi. Faktor yang melatar belakangi penggunaan model Borg and Gall yaitu faktor efesiensi tenaga biaya dan waktu yang diperlukan untuk produksi model. (Reaserch and Development) dari Borg dan Gall (1983) (1) Reaserch and information collecting (2) Planning (3) Development of the preliminary form of product (4) Preliminary field testing (5) Main product revision (Main field test (7) Operational product revision (8) Operational field testing (9) Final product (10) Dissemination and implementation. 


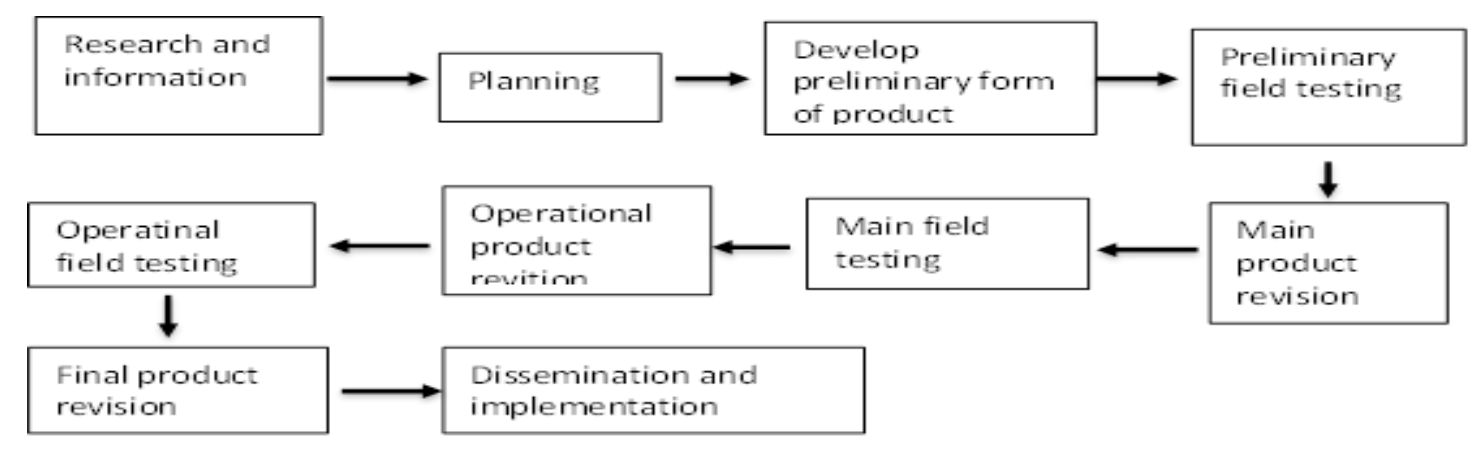

Gambar 1 Instruksional Design R and D Borg \& Gall (Wallter R. Borg and Meredith D. Gall, Educational Research: An Introdution, $4{ }^{\text {th }}$ Editio, 1983)

\section{HASIL PENELITIAN DAN PEMBAHASAN}

Berdasarkan hasil evaluasi ujicoba kelompok kecil yang dilakukan oleh peneliti bahwa terdapat 17 item model yang layak digunakan dari 25 bentuk item model yang dikembangkan, selanjutnya berdasarkan hasil uji ahli yang dilakukan untuk model latihan model latihan smash bola voli untuk pemula pada usia SMA dapat disimpulkan sebagai berikut: (1) berdasarkan uji ahli yang dilakukan terdapat 8 item model yang tidak layak untuk digunakan. (2) 8 item model tersebut terlalu sulit dan tidak cocok untuk atlet pemula.

\section{Efektifitas Model}

\section{Hasil Ujicoba Tahap Pertama/Ujicoba Kelompok Kecil}

Model latihan smash dalam permainan bola voli untuk pemula pada usia SMA telah dievaluasi oleh para ahli, model berada pada evaluasi tahap 1 yang dilakukan oleh ahli sebagai acuan peneliti dalam melaksanakan tahap berikutnya. Berikut merupakan ringkasan revisi tahap 1 berdasarkan evaluasi yang dilakukan oleh para ahli sebagai berikut: (1) Keseluruhan semua variasi model latihan smash dalam permainan bola voli untuk pemula pada usia SMA dapat dilakukan oleh atlet pemula, yang perlu diperhatikan adalah urutan tingkat kesulitan model latihan dimulai dari yang termudah hingga yang tersulit agar pelaksanaan berjalan sesuai dengan rencana dan teknik smash atlet meningkat; (2) Pada saat menerapkan model latihan smash dilapangan atlet kurang memperhatikan arahan pelatih dan tugas seorang pelatih harus selalu memantau pada saat proses latihan 
sehingga tujuan latihan smash dapat tercapai sesuai dengan tujuan yang diharapkan; (3) Demonstrasi model smash yang lebih sulit harus lebih detail dan perlahan-lahan dari setiap tahap gerakan.

\section{Hasil Uji Coba Tahap Kedua/ Uji Coba Kelompok Besar}

Setelah hasil model latihan smash dalam permainan bola voli untuk pemula pada usia SMA diujicobakan dalam skala kecil dan telah direvisi, maka langkah selanjutnya adalah melakukan ujicoba kelompok besar. Berdasarkan hasil ujicoba kelompok kecil yang telah dievaluasi oleh ahli, kemudian peneliti melakukan revisi produk awal dan memperoleh 17 item model latihan smash dalam permainan bola voli untuk pemula pada usia SMA yang akan digunakan pada ujicoba kelompok besar.

Langkah Selanjutnya setelah model mengalami revisi tahap kedua maka akan dilanjutkan dengan melakukan ujicoba produk dengan kelompok besar dengan menggunakan subjek penelitian sebanyak 60 atlet pemula pada Usia SMA yang terdiri dari siswa ekstrakulikuler bola voli di SMAI Al-Maziyyah dan SMK Bela Nusantara di Kabupaten Cianjur.

Data hasil penilaian 30 orang subjek peserta uji efektivitas model latihan smash dalam permainan bola voli untuk pemula pada usia SMA, hasil perolehan data secara keseluruhan dengan pengumpulan data dituangkan dalam skor angka, pengambilan data secara akumulatif dari setiap subjek yang diiberikan lima kali kesempatan ditunjukkan pada tabel berikut ini:

\section{Tabel 1 Nilai Rata-Rata}

\begin{tabular}{cccccc}
\hline & Mean & N & $\begin{array}{c}\text { Std. } \\
\text { Deviation }\end{array}$ & $\begin{array}{c}\text { Std. Error } \\
\text { Mean }\end{array}$ \\
\hline Pair 1 & Pre-test & 15.0500 & 30 & 1.41331 & 0.22346 \\
\hline & Posttest & 20.7500 & 30 & 1.69085 & 0.26735 \\
\hline
\end{tabular}

Nilai rata-rata atlet sebelum diberikan perlakukan model latihan smash adalah 15.05 dan nilai setelah diberikan perlakuan model latihan smash adalah 20.75 yang artinya bahwa terdapat peningkatan hasil dari pretest dan posttest sehingga kemampuan smash atlet pemula meningkat. 
Tabel 2 Koefisien Korelasi

\begin{tabular}{ccccc}
\hline & & N & Correlation & Sig. \\
\hline Pair 1 & Pre-test dan posttest & 30 & 0.821 & 0.000 \\
\hline
\end{tabular}

Berdasarkan tabel diatas didapat bahwa koefisien korelasi latihan smash sebelum dan sesudah diberikan perlakuan model latihan smash bola voli adalah .821 p-value $0,00<0,05$ jadi kesimpulannya adalah terdapat peningkatan keterampilan yang signifikan setelah diberikan model latihan smash.

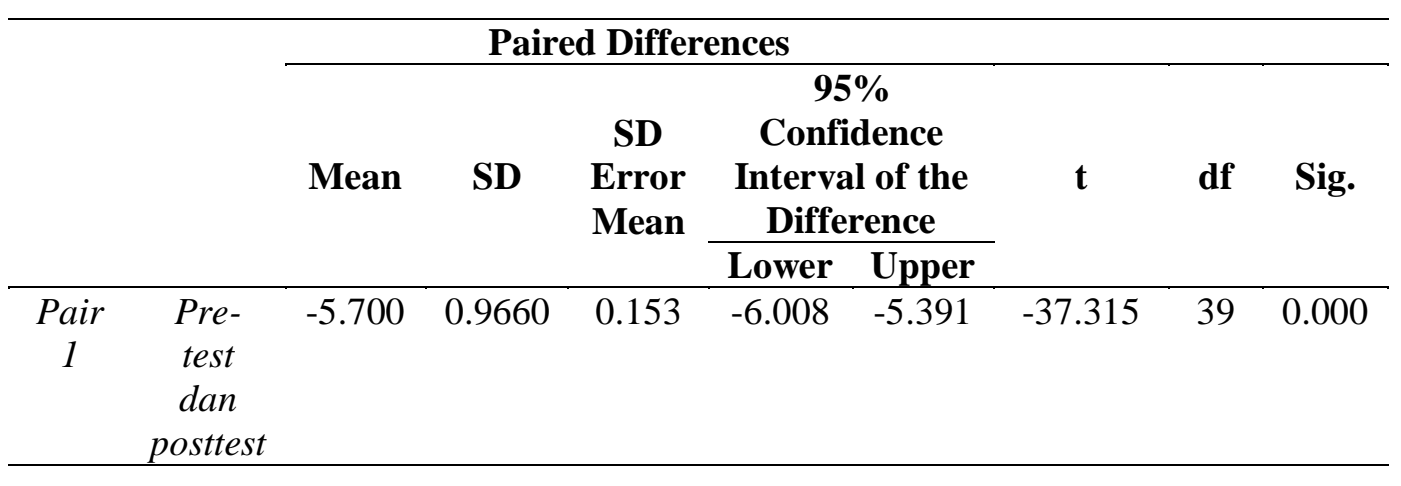

Pada uji signifikan perbedaan dengan SPSS 16 didapatkan nilai signifikasi lebih kecil dari taraf signifikansi $(0,05)$, hal ini berarti terdapat perbedaan yang signifikan antara sebelum dan sesudah diberikan perlakuan model latihan smash bola voli. Berdasarkan hasil tersebut dapat disimpulkan bahwa model latihan smash bola voli untuk pemula pada usia SMA efektif dan dapat meningkatkan kemampuan smash. Model latihan smash dalam permainan bola voli untuk pemula pada usia SMA yang telah dikembangkan memiliki efektivitas yang signifikan.

Perbandingan hasil catatan rata-rata nilai sebelum dan setelah diberikan perlakuan model latihan smash bola voli untuk pemula pada usia SMA dapat dilihat pada diagram batang berikut: 


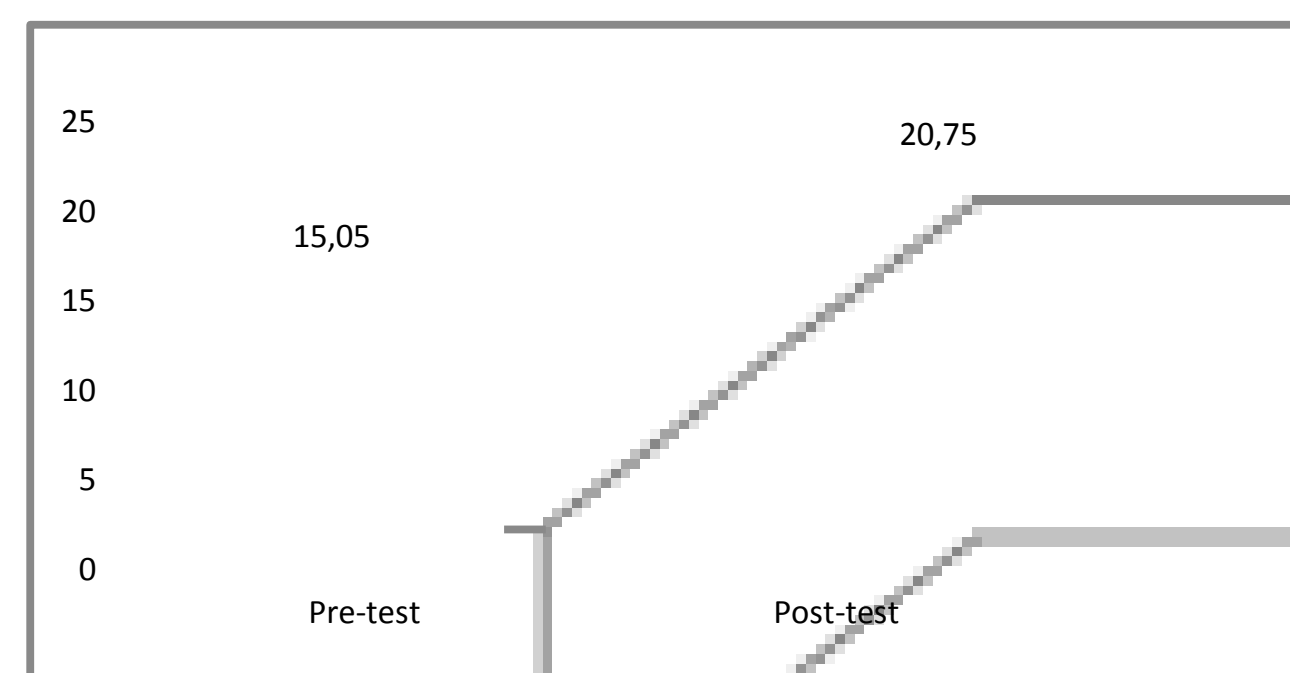

\section{Gambar 2 Diagram Batang}

\section{PEMBAHASAN}

\section{Penyempurnaan Produk}

Hasil test yang diperoleh sebelum dan setelah diberikan perlakuan dapat disimpulkan bahwa model latihan smash dalam permainan bola voli untuk pemula pada usia SMA layak dan efektif untuk dapat meningkatkan keterampilan smash atlet.

Berdasarkan dari kekurangan dan kelebihan produk yang dihasilkan terdapat beberapa masukan guna tercapainya penyempurnaan produk yang dihasilkan diantaranya: (1) Petunjuk pelaksanaan dan gambar pada model harus disusun dan dibuat dengan jelas agar mudah untuk dipahami atlet, (2) penyusunan tingkat kesulitan item model harus lebih teliti, karena kesamaan gerakan dan ketepatan penjelasan posisi; (3) model latihan smash harus sesuai dengan tujuan latihan yaitu untuk atlet pemula sehingga0dimulai dari yang termudah hingga tersulit, dan (4) fasilitas dan alat yang digunakan hendaknya harus sesuai dengan tujuan latihan. Target juga hendaknya diperhatikan kualitasnya untuk menunjang proses latihan. 


\section{Pembahasan Produk}

Model latihan smash bola voli untuk atlet pemula usia SMA ini dibuat oleh peneliti agar dapat menjadi referensi yang dapat membantu pelatih dalam memberikan variasi latihan smash pada permainan bola voli. Model ini disusun berdasarkan atas kebutuhan atlet pemula.

Setelah produk ini dievaluasi mengenai beberapa kelemahan yang ada dan dilakukan pembenahan produk untuk hasil yang lebih baik, maka dapat disampaikan beberapa keunggulan dari produk ini diantaranya: (1) Dapat meningkatkan kemampuan smash atlet, (2) model yang dihasilkan memiliki beberapa variasi dari yang termudah hingga tersulit, (3) model ini akan meningkatkan minat berlatih atlet karena terdapat beberapa variasi latihan, sehingga proses latihan tidak berjalan dengan monoton dan membosankan, (4) model latihan ini dapat membantu sebagai referensi pelatih untuk menunjang proses latihan smash bola voli pada ektrakulikuler di sekolah, dan (5) sumbangan bagi ilmu pendidikan khususnya bidang bola voli.

\section{Keterbatasan Produk}

Penelitian ini dilakukan oleh peneliti dengan sesempurna mungkin sesuai dengan kemampuan yang peneliti miliki, namun apabila didalam penelitian ini masih terdapat banyak yang harus peneliti akui dan dikemukakan. Keterbatasan tersebut yaitu (1) pada saat peneliti melakukan ujicoba lapangan sebaiknya dilakukan pada ruang lingkup yang lebih besar, (2) sarana dan prasarana yang digunakan kurang memadai dan masih terbatas, (3) produk yang dibuat masih jauh dari sempurna, dan (4) penjelasan yang diberikan pada gambar latihan smash masih kurang sempurna.

\section{SIMPULAN}

Hasil dari data yang peneliti peroleh dari ujicoba lapangan menunjukan bahwa terjadi peningkatan pada kelompok ujicoba yang diberikan perlakuan model latihan smash dapat dilihat dari hasil pretest dan hasil postes yang terdapat peningkatan nilai rata-rata kemampuan subjek. Pembahasan hasil penelitian dapat 
disimpulkan bahwa (1) menghasilkan produk akhir berupa model latihan smash dalam permainan bola voli untuk pemula, (2) model latihan smash dapat mempermudah peroses latihan dan meningkatkan kemampuan smash yang bervariasi dan mematikan

\section{DAFTAR PUSTAKA}

Ahmadi, N. 2007. Panduan Olahraga Bola Voli. Surakarta: Era Pustaka Utama. Bompa, T., O. 2009 Periodization Theory and Methodology of Training. United States: Human Kinetic.

Borg, Walter R. and Meredith D. Gall. 1983. Educational research and introduction. Newyork: Logman.

Lumintuarso, R. 2013. Teori Kepelatihan Olahraga. Jakarta: LANKOR.

Pranopik, M., R. 2017. Pengembangan Variasi Latihan Smash Bola Voli. Jurnal Prestasi. p-ISSN: 2549-9394 e-ISSN: 2579-7093.Vol. 1 No. 1, Juni 2017.

Riyadi, S. 2015. Pengaruh Perbedaan Latihan Terhadap Kemampuan Smash Bola Voli. dalam Jurusan Pendidikan Olahraga dan Kesehatan Fkip UNS Surakarta. Sport Science, Vol. 01 No. 01. 